\title{
Bisthiadiazole-fused Tetraazapentacenequinone: An Air-Stable Solution-Processable n-Type Organic Semiconductor
}

Diego Cortizo-Lacalle, ${ }^{\mathrm{a}}$ Cristian Gozalvez, ${ }^{\mathrm{a}}$ Mikel Olano, ${ }^{\mathrm{a}}$ Xiangnan Sun, ${ }^{\mathrm{b}}$ Manuel MelleFranco, ${ }^{\mathrm{c}}$ Luis Hueso ${ }^{\mathrm{b}, \mathrm{d}}$ and Aurelio Mateo-Alonso ${ }^{\mathrm{a}, \mathrm{d} *}$

${ }^{a}$ POLYMAT, University of the Basque Country UPV/EHU, Avenida de Tolosa 72, E-20018 Donostia-San Sebastian, Spain

${ }^{b}$ CIC nanoGUNE Consolider, Avenida de Tolosa 76, E-20018 Donostia-San Sebastian, Spain

${ }^{c}$ Centro ALGORITMI, Universidade do Minho. 4710-057 Braga, Portugal

${ }^{d}$ Ikerbasque, Basque Foundation for Science, E-48011 Bilbao, Spain 


\section{Synthesis and Characterization}

Reagents for synthesis were, if not otherwise specified, purchased from Aldrich, Fluka or Acros. Commercial chemicals and solvents were used as received. Anhydrous THF was dried using an Innovative Pure Solve Solvent Purification System. Column chromatography was carried out using Silica gel $60(40-60 \mu \mathrm{m})$ from Scharlab. Analytical thin layer chromatography (TLC) was done using aluminum sheets $(20 \times 20$ $\mathrm{cm})$ pre-coated with silica gel RP-18W 60 F254 from Merck. UV-active compounds were detected with a UV-lamp from CAMAG at wavelength $\lambda=254$ or $366 \mathrm{~nm}$.

NMR spectra were recorded on Bruker Avance 400 spectrometer at $298 \mathrm{~K}$ using partially deuterated solvents as internal standards. Coupling constants $(J)$ are denoted in $\mathrm{Hz}$ and chemical shifts $(\delta)$ in ppm. Multiplicities are denoted as follows: $\mathrm{s}=$ singlet, $\mathrm{d}=$ doublet, $\mathrm{t}=$ triplet, $\mathrm{m}=$ multiplet, $\mathrm{br}=$ broad.

Matrix Assisted Laser Desorption Ionization (coupled to a Time-Of-Flight analyzer) experiments (MALDI-TOF) were recorded on Bruker REFLEX spectrometer in POLYMAT by Dr. Antonio Veloso.

Absorption and emission spectra were recorded on a Perkin-Elmer Lambda 950 spectrometer, and a LS55 Perkin-Elmer Fluorescence spectrometer, respectively.

Electrochemical measurements were carried out on a Princeton Applied Research Parstat 2273 in a 3-electrode single compartment cell with Pt disc working electrode ( $=0.5 \mathrm{~mm})$, a platinum wire counter electrode $(\varnothing=0.5 \mathrm{~mm})$ and a silver wire pseudoreference electrode. The cell and the electrodes were custom made. All the values are quoted versus the redox potential of the ferrocene/ferrocenium couple.

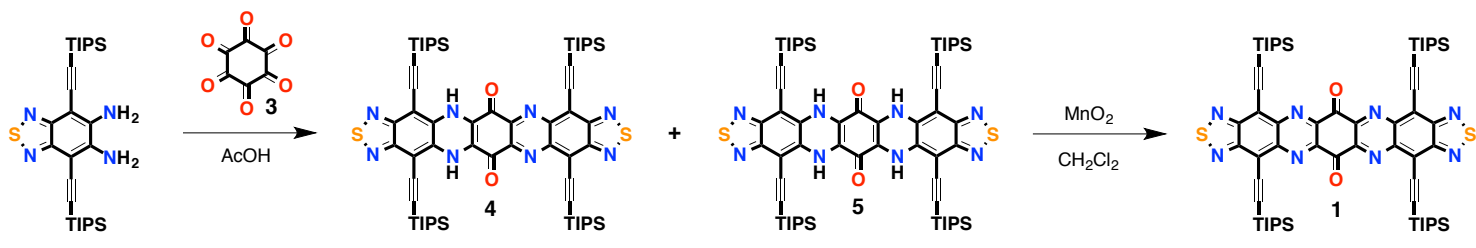


Synthesis of 4,8,12,16-tetrakis((triisopropylsilyl)ethynyl)-5,15-dihydro-6H,14H$[1,2,5]$ thiadiazolo $\left[3{ }^{\prime}, 4^{\prime}: 6,7\right] q u i n o x a l i n o[2,3-b][1,2,5]$ thiadiazolo[3,4-i]phenazine6,14-dione (4) and 4,8,12,16-tetrakis((triisopropylsilyl)ethynyl)-5,7,13,15tetrahydro-6H,14H-[1,2,5] thiadiazolo $\left[3^{\prime}, 4^{\prime}: 6,7\right]$ quinoxalino $[2,3-$ b] $[1,2,5]$ thiadiazolo[3,4-i]phenazine-6,14-dione (5)

Compound 2 (920 mg, $1.74 \mathrm{mmol}, 2.35 \mathrm{eq})$ and hexaketocyclohexane octahydrate (230 $\mathrm{mg}, 0.74 \mathrm{mmol}, 1.0 \mathrm{eq})$ were suspended in acetic acid $(20 \mathrm{~mL})$ and the mixture was refluxed for 48 hours. The reaction mixture was diluted in water, extracted with dichloromethane and washed with $\mathrm{NaHCO}_{3}$ (aq) and water. The organic phase was dried over magnesium sulphate and evaporated under reduced pressure in the rotavapor. The dark solids were purified by column chromatographic column using an eluent mixture (hexane:dichloromethane, 3:1). Two dark solids were isolated; 4: purple solid (120 mg, 14\%); 5: red solid (180 mg, 21\%).

Compound 4: ${ }^{1} \mathrm{H}$ NMR $\left(\mathrm{CDCl}_{3}\right)$ : $7.79(\mathrm{~s}, 2 \mathrm{H})$, and 1.35-1.18 (m, 84 H); ${ }^{13} \mathrm{C} \mathrm{NMR}$ $\left(\mathrm{CDCl}_{3}\right): 170.16,155.71,152.26,144.33,142.10,137.08,129.75,117.34,113.88$, 107.68, 100.31, 98.30, 96.35, 18.95, 11.66 and 11.42; EM (MALDI-TOF) (m/z): calculated for $\mathrm{C}_{62} \mathrm{H}_{86} \mathrm{~N}_{8} \mathrm{O}_{2} \mathrm{~S}_{2} \mathrm{Si}_{4}: 1150.839$; found: $1151.515\left[\mathrm{M}+\mathrm{H}^{+}\right], 1173.499$ $\left[\mathrm{M}+\mathrm{Na}^{+}\right]$.

Compound 5: ${ }^{1} \mathrm{H}$ NMR $\left(\mathrm{CDCl}_{3}\right): 6.95(\mathrm{~s}, 4 \mathrm{H})$, and 1.36-1.14 (m, 84 H); ${ }^{13} \mathrm{C} \mathrm{NMR}$ $\left(\mathrm{CDCl}_{3}\right): 169.51,152.44,138.69,119.81,105.97,97.00,96.08,18.90$ and 11.37; EM (MALDI-TOF) (m/z): calculated for $\mathrm{C}_{62} \mathrm{H}_{88} \mathrm{~N}_{8} \mathrm{O}_{2} \mathrm{~S}_{2} \mathrm{Si}_{4}$ : 1152.555; found: 1152.523 $\left[\mathrm{M}^{+}\right], 1175.504\left[\mathrm{M}+\mathrm{Na}^{+}\right]$.

Synthesis of $\quad 4,8,12,16$-tetrakis((triisopropylsilyl)ethynyl)-6H,14H $[1,2,5]$ thiadiazolo[ $\left[3^{\prime}, 4^{\prime}: 6,7\right] q u i n o x a l i n o[2,3-b][1,2,5]$ thiadiazolo $[3,4-i]$ phenazine6,14-dione (1)

Compound 4 (120 mg, 0.10mmol) and compound 5 (180 mg, $0.16 \mathrm{mmol})$ were dissolved in dichloromethane $(30 \mathrm{~mL})$ and manganese oxide (activated, 90\%) was added. The recation was stirred at room temperature for 3 hours (followed by TLC). The reaction mixture was filtrated over celite, and the solvent was evaporated under reduced pressure in the rotavapor. The solid was dissolved in dichloromethane and precipitated from methanol several times to give a dark green solid (259 mg, 87\%)

${ }^{1} \mathrm{H}$ NMR $\left(\mathrm{CDCl}_{3}\right)$ : 1.46-1.22 (m, $\left.84 \mathrm{H}\right) ;{ }^{13} \mathrm{C} \mathrm{NMR}\left(\mathrm{CDCl}_{3}\right): 177.30,156.24,145.11$, 142.60, 117.89, 116.08, 100.59, 19.00 and 11.71; EM (MALDI-TOF) (m/z): calculated for $\mathrm{C}_{62} \mathrm{H}_{84} \mathrm{~N}_{8} \mathrm{O}_{2} \mathrm{~S}_{2} \mathrm{Si}_{4}$ : 1148.524 ; found: $1149.525\left[\mathrm{M}+\mathrm{H}^{+}\right], 1173.504\left[\mathrm{M}+\mathrm{Na}^{+}\right]$; UV-Vis $\log (\varepsilon): 267$ (4.91), 282 (4.92), 387 (5.12) and 646 (4.3). 


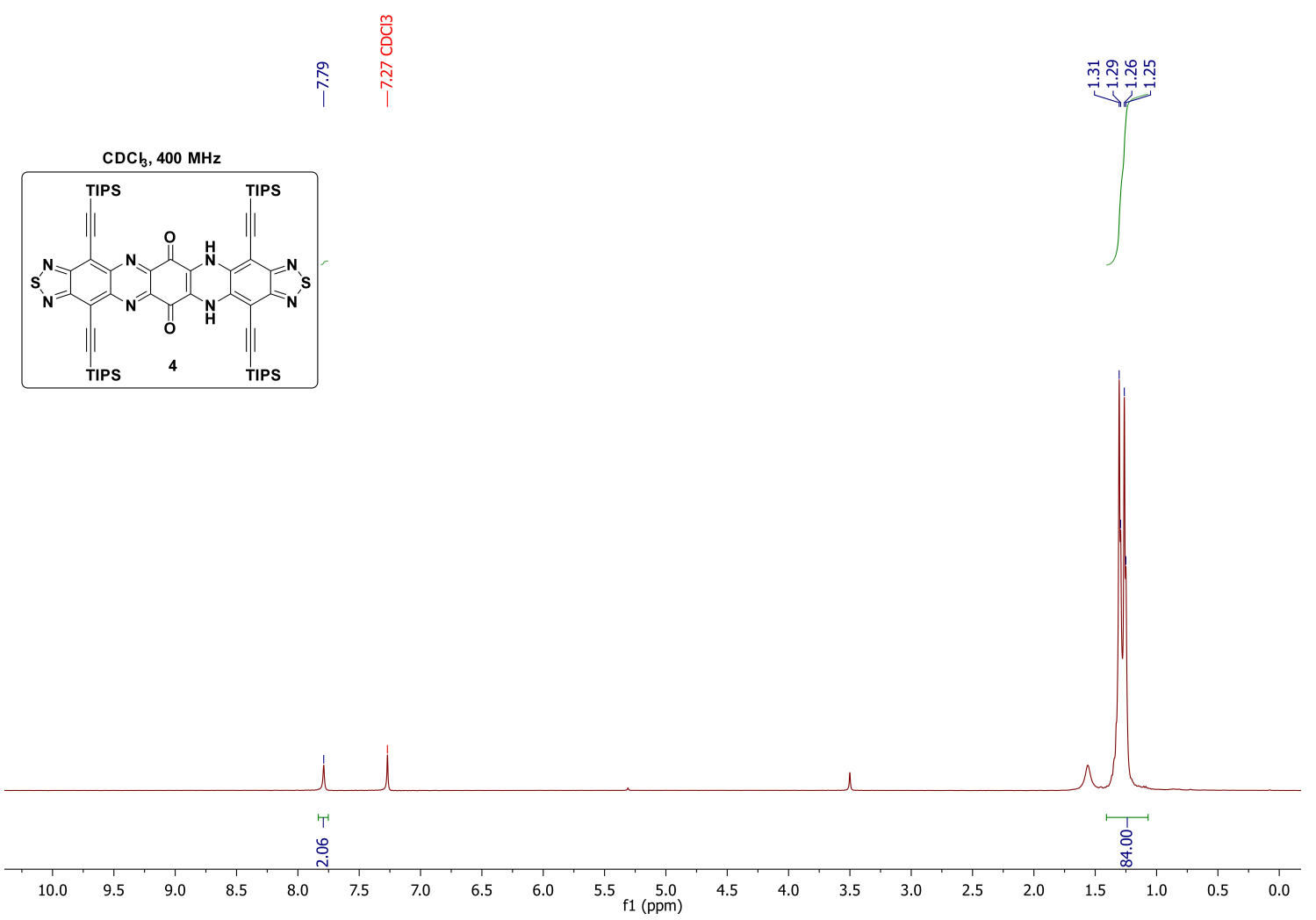

Figure S1. ${ }^{1} \mathrm{H}-\mathrm{NMR}$ spectrum of compound $\mathbf{4}\left(\mathrm{CDCl}_{3}, 400 \mathrm{MHz}\right)$.
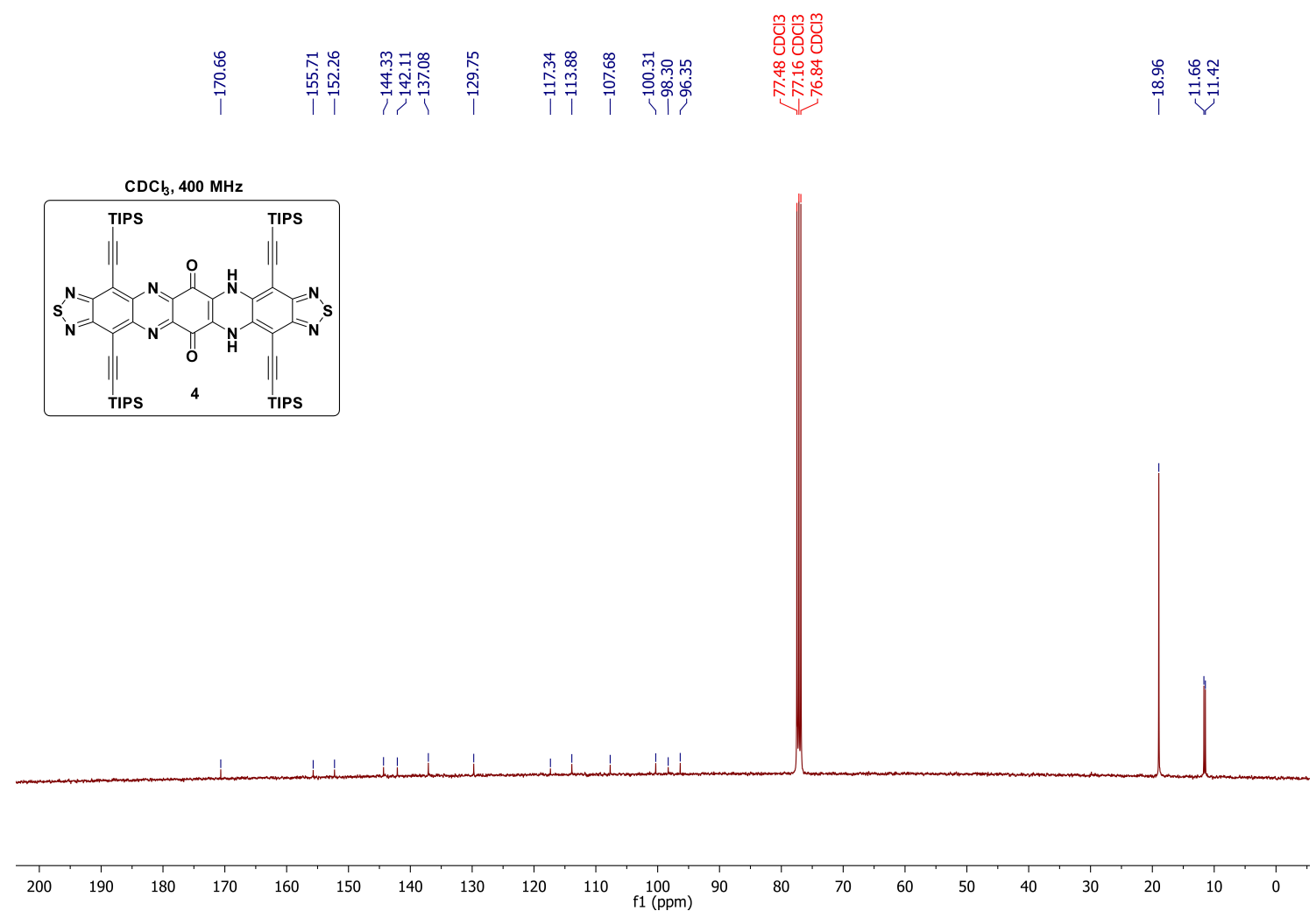

Figure S2. ${ }^{13} \mathrm{C}-\mathrm{NMR}$ spectrum of compound $\mathbf{4}\left(\mathrm{CDCl}_{3}, 400 \mathrm{MHz}\right)$. 

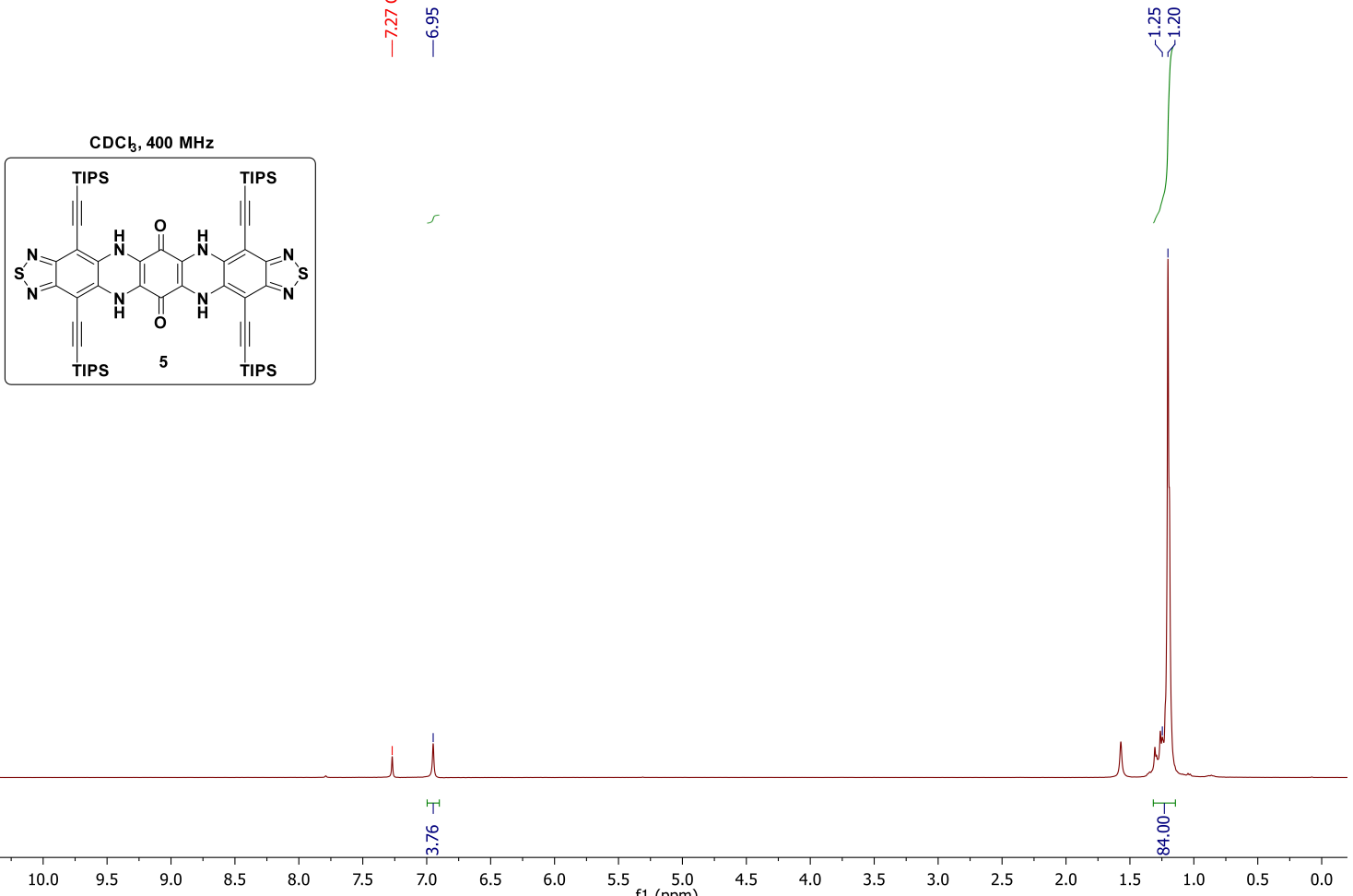

Figure S3. ${ }^{1} \mathrm{H}-\mathrm{NMR}$ spectrum of compound $\mathbf{5}\left(\mathrm{CDCl}_{3}, 400 \mathrm{MHz}\right)$.

\begin{tabular}{|c|c|c|c|c|}
\hline & 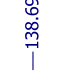 & $\begin{array}{l}\overrightarrow{0} \\
\stackrel{0}{\vec{j}} \\
\overrightarrow{\mid}\end{array}$ & & $\begin{array}{l}80 \\
0.0 \\
0.0 \\
11\end{array}$ \\
\hline
\end{tabular}

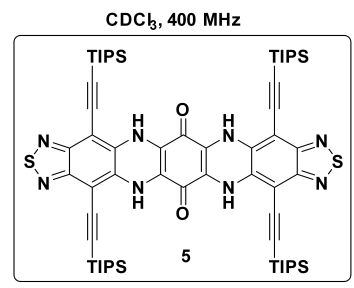

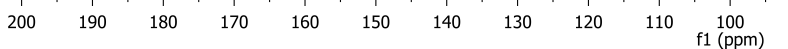

Figure S4. ${ }^{13} \mathrm{C}-\mathrm{NMR}$ spectrum of compound $5\left(\mathrm{CDCl}_{3}, 400 \mathrm{MHz}\right)$. 


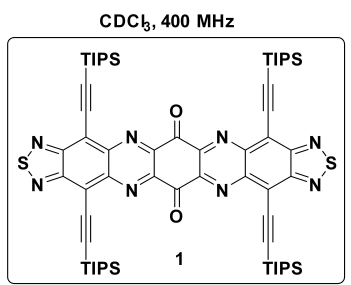

\section{के}

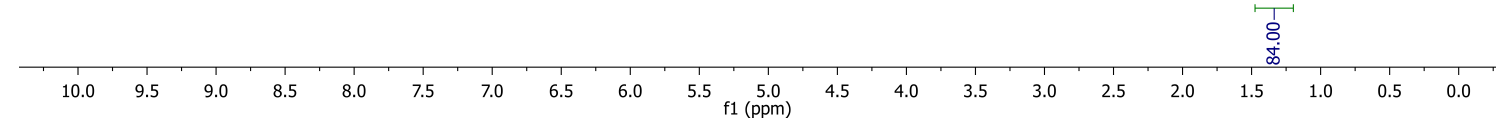

Figure S5. ${ }^{1} \mathrm{H}-\mathrm{NMR}$ spectrum of compound $1\left(\mathrm{CDCl}_{3}, 400 \mathrm{MHz}\right)$.

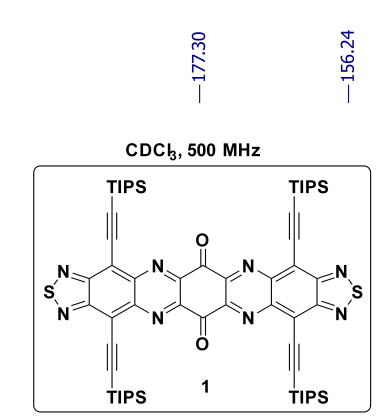

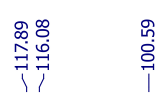

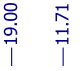

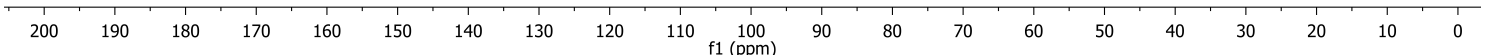

Figure S6. ${ }^{13} \mathrm{C}-\mathrm{NMR}$ spectrum of compound $\mathbf{1}\left(\mathrm{CDCl}_{3}, 400 \mathrm{MHz}\right)$. 


\section{Thermal properties}

TGA Q500 TA Instruments was used to perform the thermogravimetric analysis (TGA) using a $10{ }^{\circ} \mathrm{C} / \mathrm{min}$ heating rate under a nitrogen flow, which was changed to oxygen from $800{ }^{\circ} \mathrm{C}$. DSC 822 Mettler Toledo was used to carry out differential scanning calorimetry (DSC). The sample was sealed in an aluminum pan, and measured at a scanning rate of $10{ }^{\circ} \mathrm{C} / \mathrm{min}$ under a nitrogen flow. Temperatures were taken from the onset of the transition.

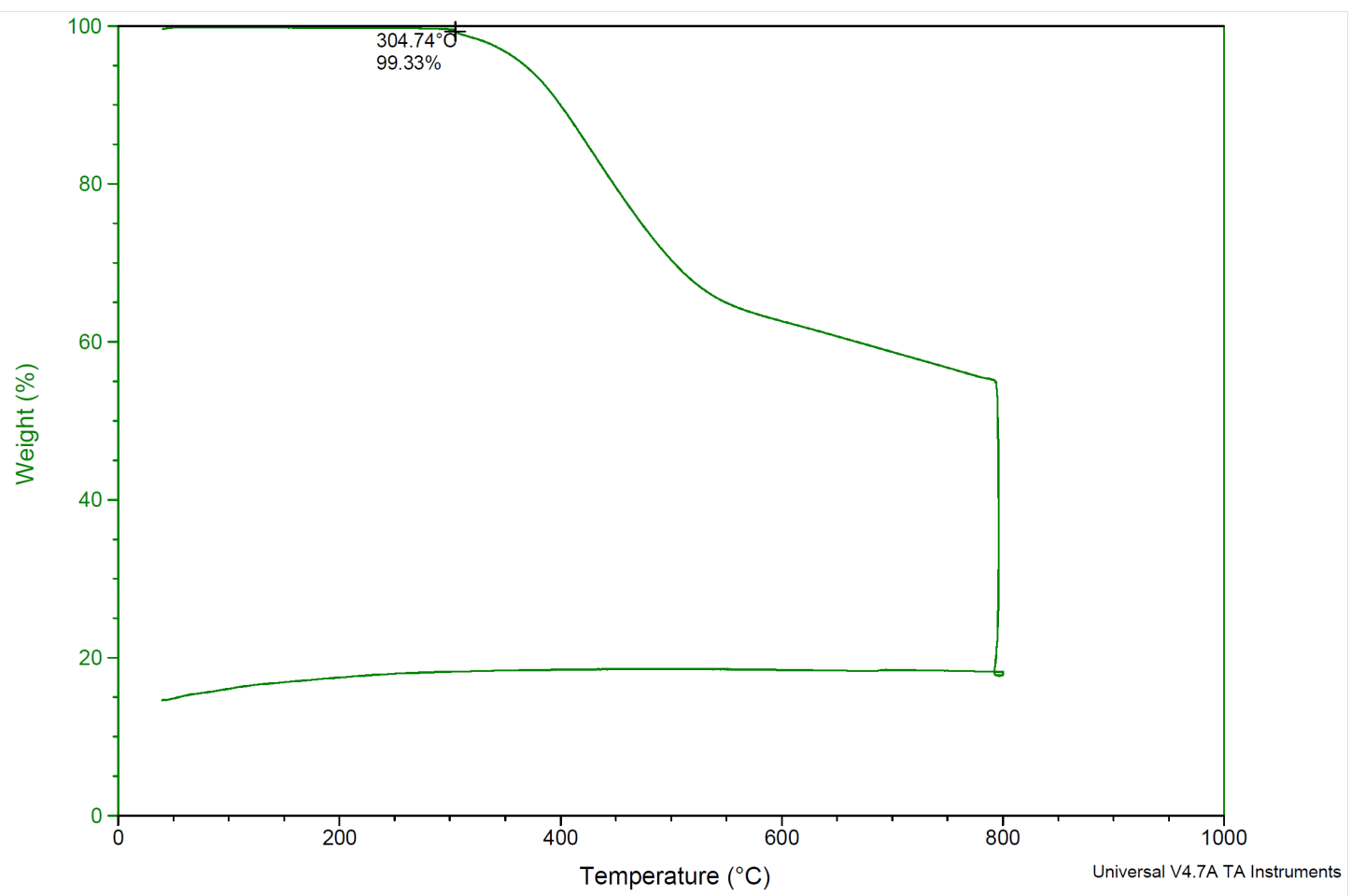

Figure S7. TGA of compound 1

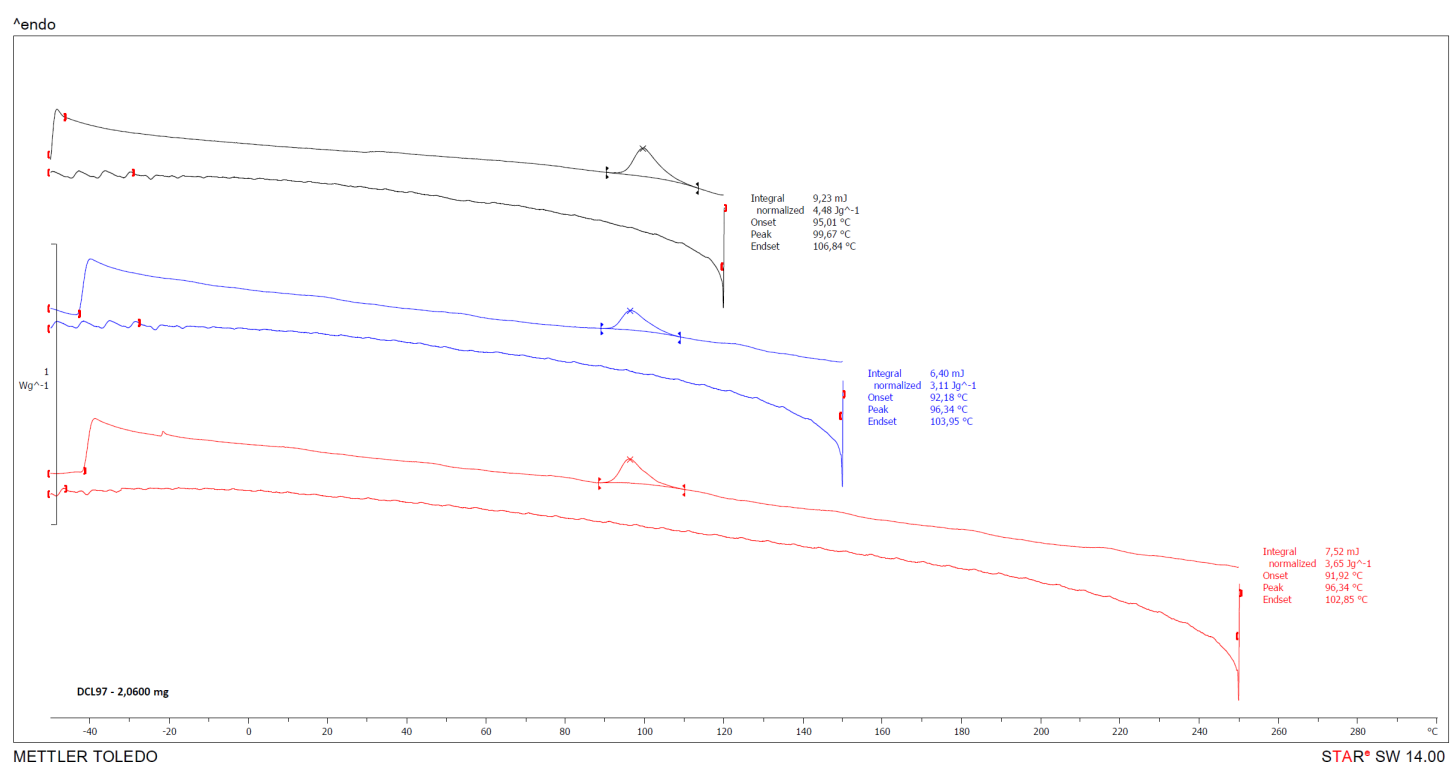

Figure S8. DSC of compound 1 


\section{Single Crystal X-Ray Diffraction}

X-ray diffraction experiments were performed by the X-ray diffraction unit of General Services SG-Iker (UPV/EHU) by Dr. Leire San Felices. Intensity data were collected on an Agilent Technologies Super-Nova diffractometer, which was equipped with monochromated $\mathrm{Cu} k \alpha$ radiation $(\lambda=1.54184 \mathrm{~A})$ and Atlas CCD detector. Measurement was carried out at 100(2) $\mathrm{K}$ with the help of an Oxford Cryostream 700 PLUS temperature device. Data frames were processed (united cell determination, analytical absorption correction with face indexing, intensity data integration and correction for Lorentz and polarization effects) using the Crysalis software package. The structure was solved using Olex2 and refined by full-matrix least-squares with SHELXL-97. Final geometrical calculations were carried out with Mercury and PLATON as integrated in WinGX.

\section{OFET Device Fabrication and Thin Film Characterization.}

Bottom-gate bottom-contact field-effect transistor (FET) configuration have been employed. In these transistors, gold electrodes (4-nm $\mathrm{Cr}$ plus 50-nm Au) have been patterned as source and drain by a photolithography method on $\mathrm{Si}_{-} \mathrm{SiO}_{2}$ (300-nm, thermal growth) substrates. First, the electrodes were cleaned one by one by ultrasonication with electronic grade acetone and isopropanol and dried under compressed nitrogen. To form self-assembled monolayers (SAMs) of hexamethyldisilazane (HMDS) on the $\mathrm{SiO}_{2}$ surface, the substrates were treated with a vapor prime oven at $150^{\circ} \mathrm{C}$ during 15 minutes. Solutions of compound $1(8 \mathrm{mg} / \mathrm{mL})$ in chloroform and chlorobenzene were prepared and after filtration, films of compound $\mathbf{1}$ were formed by spin-coating over the modified substrates. A series of compound 1based TFTs were built with channel lengths ranging from 10 to $50 \mu \mathrm{m}$ and with channel width/length (W/L) ratios from 100 to 10000 . Mobility, Threshold voltage $\left(\mathrm{V}_{t}\right)$ and on/off ratio current $\left(\mathrm{I}_{\mathrm{on}} / \mathrm{off}\right)$ for the different devices, as well as the average electron mobility for compound 1 at each substrate temperature are presented.

Table S1. Parameters obtained from the measurement of the Organic Thin Film Transistors (OTFTs).

\begin{tabular}{|c|c|c|c|c|c|c|c|}
\hline & \multicolumn{3}{|c|}{ Chloroform } & \multicolumn{4}{|c|}{ Chlorobenzene } \\
\hline & $50^{\circ} \mathrm{C}$ & $80^{\circ} \mathrm{C}$ & $100^{\circ} \mathrm{C}$ & $50^{\circ} \mathrm{C}$ & $80^{\circ} \mathrm{C}$ & $100^{\circ} \mathrm{C}$ & $100^{\circ} C^{a)}$ \\
\hline Mobility ave. $\left(\mathrm{cm}^{2} / \mathrm{Vs}\right)$ & $6.6010^{-5}$ & $1.5710^{-4}$ & $5.5310^{-4}$ & $0.8810^{-3}$ & $0.8310^{-3}$ & $0.7710^{-3}$ & $0.7710^{-3}$ \\
\hline $\begin{array}{l}\text { Mobility max. } \\
\quad\left(\mathrm{cm}^{2} / \mathrm{Vs}\right)\end{array}$ & $1.1410^{-4}$ & $3.6510^{-4}$ & $1.1810^{-3}$ & $2.4210^{-3}$ & $1.4710^{-3}$ & $1.2210^{-3}$ & $1.2910^{-3}$ \\
\hline Threshold voltage (V) & 30 & 25 & 10 & 9 & 9 & 9 & 24 \\
\hline $\mathbf{I}_{\mathbf{o n}} / \mathbf{I}_{\mathbf{o f f}}$ & $<10^{2}$ & $10^{2}$ & $>10^{2}$ & $<10^{2}$ & $<10^{2}$ & $<10^{2}$ & $10^{3}$ \\
\hline
\end{tabular}

a) Measured at ambient conditions 

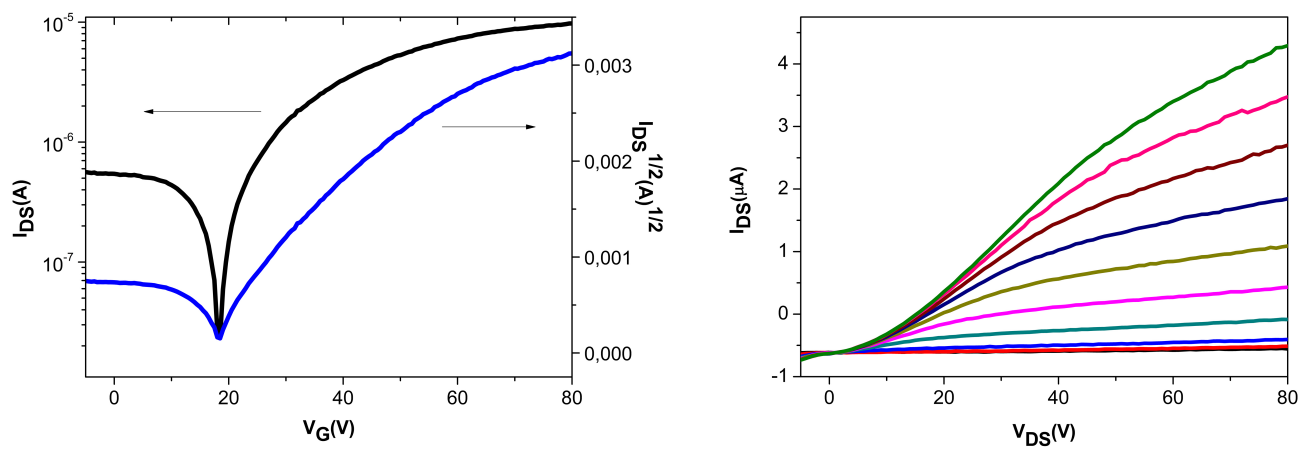

Figure S9. Representative transfer (left) and output 0-60 V (right) curves of thin films of $\mathbf{1}$ in air.

\section{FRONTIER ORBITALS and ENERGIES}

Table S2 presents the frontier orbitals energies and the HOMO-LUMO gap for benzoquinone-bridged bisdiazanaphthothiadiazole. The experimental LUMO $(-4.46 \mathrm{eV})$ is very similar to the calculated one in vacuum and $\mathrm{CH}_{2} \mathrm{Cl}_{2}$, also the calculated band gap is $\sim 1.8 \mathrm{eV}$ fits well the estimated experimentally $(1.77 \mathrm{eV})$. HOMO and HOMO-1 are almost degenerate and have very similar densities. Interestingly, the HOMO-2 appears at a much lower energy, is more localized and does not have any density in the aromatic (cyclic) part of the molecule (not shown here).

Table S2. Frontier orbitals at the B3LYP-6-311g+(d2,p) level in $\mathrm{CH}_{2} \mathrm{Cl}_{2}$ and in vacuum. All values in eV.

\begin{tabular}{|l|l|l|l|l|l|l|l|l|l|}
\hline Symm. & Model & State & LUMO+2 & LUMO+1 & LUMO & HOMO & HOMO-1 & HOMO-2 & gap \\
\hline $\mathrm{C}_{1}$ & Full Molecule & $\mathrm{CH}_{2} \mathrm{Cl}_{2}$ & -3.34 & -3.83 & $\mathbf{- 4 . 3 8}$ & $\mathbf{- 6 . 1 6}$ & -6.2 & -7.0 & $\mathbf{1 . 7 8}$ \\
\hline $\mathrm{C}_{1}$ & Full Molecule & Vacuum & -3.38 & -3.91 & -4.45 & -6.19 & -6.23 & -7.11 & 1.74 \\
\hline
\end{tabular}

In addition, we have calculated two benzoquinone-bridged bisdiazanaphthothiadiazole analogs: 1) without TIPS functionalization and 2) without TIPS and quinone functionalization, Table S3. The frontier orbital energies are similar with and without TIPS (without TIPS the system has a slightly more stable HOMO and LUMO). The analog molecule where the oxygen atoms of the quinone group have been substituted by $\mathrm{H}$ has a large effect on the band gap, which is $1 \mathrm{eV}$, that is $1 \mathrm{eV}$ less: $\sim 75 \%$ from destabilization of the HOMO (with higher energy) and $\sim 25 \%$ from stabilization of the LUMO (with lower energy).

Table S3. Frontier orbitals at the B3LYP-6-311g+(d2,p) level in $\mathrm{CH}_{2} \mathrm{Cl}_{2}$ and in vacuum for the molecule without TIPS functionalization and $\mathrm{c}$ ) the molecule without TIPS functionalization and with the carbonyl groups substituted by $>\mathrm{C}-\mathrm{H}$. All values in $\mathrm{eV}$.

\begin{tabular}{|l|l|l|l|l|l|l|l|l|l|}
\hline Symm. & Model & State & LUMO+2 & LUMO+1 & LUMO & HOMO & HOMO-1 & HOMO-2 & gap \\
\hline $\mathrm{D}_{2 \mathrm{~h}}$ & Without TIPS & $\mathrm{CH}_{2} \mathrm{Cl}_{2}$ & -3.48 & -3.96 & -4.53 & -6.5 & -6.54 & -7.53 & 2.0 \\
\hline $\mathrm{D}_{2 \mathrm{~h}}$ & Without TIPS & vacuum & -3.45 & -4.04 & -4.58 & -6.54 & -6.56 & -7.38 & 2.0 \\
\hline $\mathrm{D}_{2 \mathrm{~h}}$ & $\begin{array}{l}\text { No TIPS } \\
\text { No QUINONE }\end{array}$ & $\mathrm{CH}_{2} \mathrm{Cl}_{2}$ & -2.68 & -3.88 & -4.79 & -5.74 & -6.3 & -7.24 & 1.0 \\
\hline $\mathrm{D}_{2 \mathrm{~h}}$ & $\begin{array}{l}\text { No TIPS } \\
\text { No QUINONE }\end{array}$ & vacuum & -2.68 & -3.87 & -4.78 & -5.75 & -6.3 & -7.24 & 1.0 \\
\hline
\end{tabular}

